\title{
STRATEGI PERUSAHAAN DALAM MENGHADAPI DILEMA KEBUTUHAN TENAGA PENYADAP DI KEBUN NGOBO KABUPATEN SEMARANG
}

\author{
Company's Strategy In Facing The Needs Of Tapper Workers In Ngobo Garden \\ Semarang District \\ Christian Vieri ${ }^{1}$, Hendrik Johannes Nadapdap ${ }^{2}$ \\ Program Studi Agribisnis, Fakultas Pertanian dan Bisnis, \\ Universitas Kristen Satya Wacana Salatiga \\ E-mail : $\underline{522015062 @ s t u d e n t . u k s w . e d u}, \underline{\text { hendrik.nadapdap@uksw.edu }}$
}

\begin{abstract}
This study aims to: (1) Identifying dilemma (between expectations and reality) any faced by the company in selecting the workforce needs in Ngobo Gardens; (2) Determine the company's strategy in facing the dilemma of manpower needs in Ngobo Gardens. The use of qualitative approach research methods with qualitative descriptive design. Determination of informants and key informants in this study using purposive sampling technique. The results showed that (1) The dilemma needs of tappers on: Human Resource Management (HRM), includes procurement of power tappers, labor compensation tapper, tapping energy strategy of maintaining loyalty, employee management plans eavesdroppers. While forecasting Human Resources, including factors that affect employee tapper forecast, procurement plans tapper employee, the employee needs tapper planning constraints; (2) Strategy Ngobo Gardens in facing a dilemma include: energy procurement strategy tapper, strategy keeping the loyalty of power tappers, and strategies in the face of factors that affect employee forecast eavesdroppers.
\end{abstract}

Keywords : Strategy; Dilemma company needed Manpower; Gardens Ngobo; Tapping Power.

Abstrak
Penelitian ini bertujuan untuk : (1) Mengidentifikasi dilema (antara harapan dan kenyataan) apa saja yang dihadapi oleh perusahaan dalam memilih kebutuhan tenaga kerja di Kebun Ngobo; (2) Mengetahui strategi perusahaan dalam menghadapi dilema kebutuhan tenaga kerja di Kebun Ngobo. Metode penelitian ini menggunakan pendekatan kualitatif dengan desain deskriptif kualitatif. Penentuan informan dan key informan pada penelitian ini menggunakan teknik purposive sampling. Hasil penelitian menunjukan bahwa (1) Dilema kebutuhan tenaga penyadap mengenai : Manajemen Sumber Daya Manusia (MSDM), meliputi pengadaan tenaga penyadap, kompensasi tenaga kerja penyadap, strategi menjaga loyalitas tenaga penyadap, rencana penanganan karyawan penyadap. Sedangkan peramalan Sumber Daya Manusia, meliputi faktor-faktor yang mempengaruhi ramalan karyawan penyadap, rencana pengadaan karyawan penyadap, hambatan perencanaan kebutuhan karyawan penyadap; (2) Strategi Kebun Ngobo dalam menghadapi dilema meliputi: strategi pengadaan tenaga penyadap, strategi menjaga loyalitas tenaga penyadap, dan strategi dalam menghadapi faktor-faktor yang mempengaruhi ramalan karyawan penyadap.

Kata Kunci : Strategi; Dilema Kebutuahan Tenaga Kerja; Kebun Ngobo; Tenaga Penyadap.

Sitasi: Christian Vieri1, Hendrik Johannes Nadapdap, 2019. Strategi Perusahaan Dalam Menghadapi Dilema Kebutuhan Tenaga Penyadap Di Kebun Ngobo Kabupaten Semarang, JSEP 15 (3): 215 - 228. 


\section{Pendahuluan}

Sumber daya manusia mempunyai peranan sangat penting dalam menentukan keberhasilan suatu perusahaan. Sumber daya manusia yang berkualitas dapat menjadi tolak ukur sebagai sistem perusahaan yang sudah baik. "Manusia merupakan sumber daya yang paling bernilai, dan ilmu perilaku menyiapkan banyak teknik dan program yang dapat menuntun pemanfaatan sumber daya manusia secara lebih efektif". Hal ini bertujuan untuk mencapai kinerja sumber daya manusia yang semakin meningkat dan memberikan nilai tambah bagi perusahaan (Prihantoro, 2012).

PT Perkebunan Nusantara IX (PTPN IX) merupakan sebuah badan usaha milik negara yang bergerak dalam bidang perkebunan dengan dua divisi tanaman budidaya yaitu divisi tanaman tahunan dan divisi tanaman semusim. Pada divisi tanaman tahunan salah satu komoditinya adalah karet. Salah satu unit kebun dari PTPN IX yang membudidayakan tanaman karet adalah Kebun Ngobo, dengan luas kebun 2.257,44 ha yang dibagi kedalam empat Afdeling yaitu: Setro, Klepu, Jatirunggo dan Gebugan. PTPN IX sendiri menyadari bahwa kelangsungan hidup dan pertumbuhan sebuah perusahaan tidak hanya ditentukan dari keberhasilannya dalam mengelola finansial yang berdasarkan pada kekuatan modal atau uang semata, melainkan juga ditentukan dari keberhasilannya mengelola sumber daya manusia (PTPN IX, 2014).

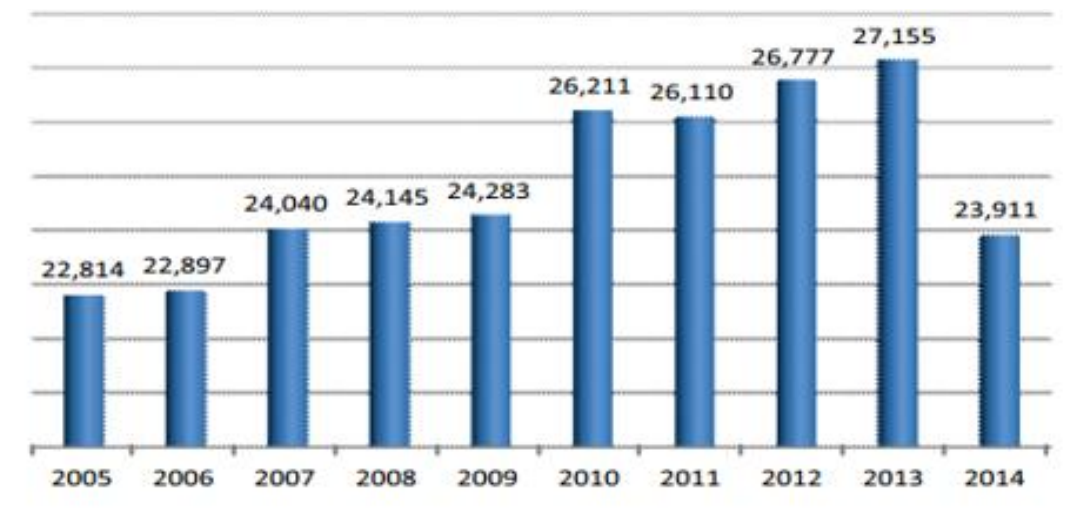

Gambar 1. Hasil Produksi Karet PTPN IX

Sumber : PTPN IX 2014 (https://ptpnix.co.id)

Pada gambar diatas dapat diketahui bahwa produksi karet di PTPN IX dengan pencapaian tertinggi pada tahun 2013 yaitu 27.155 ton dan pada tahun 2014 hanya 23,991 ton dan merupakan produksi terendah selama 10 tahun terakhir, hal ini disebabkan turunnya harga karet dan tingginya biaya panen, sehingga karet dipanen dalam batas optimalnya saja (PTPN IX, 2014). Menurut (Suheerman, 2009) salah satu faktor yang menyebabkan produksi turun maupun meningkat adalah pengelolaan sumber daya manusia yang sudah baik.

Strategi sumber daya manusia adalah seperangkat proses-proses dan aktivitas yang dilaksanakan bersamaan oleh Manajer sumber daya manusia dan Manajer lini untuk menyelesaikan masalah bisnis yang terkait dengan manusia. Kegiatan strategi sumber daya manusia dapat didasarkan pada : kerjasama antara Manajer sumber daya manusia dan Manajer 
lini dalam mengelola sumber daya manusia yang menekankan pada "people related business concerns", untuk mencapai tujuan strategi bisnis yang ditetapkan, yaitu meningkatkan kinerja bisnis saat ini dan masa depan serta menghasilkan keunggulan bersaing berkelanjutan (people related busuness issue). (Widajanti, 2007)

Perekrutan adalah sebagai proses penarikan sejumlah calon pekerja yang berpotensi untuk diseleksi menjadi karyawan perusahaan dan dapat juga diartikan, penarikan (recruitment) adalah tindakan yang paling penting dalam pengadaan tenaga kerja. Penarikan dianggap berhasil jika banyak pelamar yang memasukkan lamarannya ke perusahaan sehingga peluang untuk mendapatkan karyawan yang sesuai dengan harapan terbuka lebar dan perusahaan dapat memilih terbaik dari yang baik. Perusahaan tentu sudah meramalkan sumber daya yang seperti apa yang mereka butuhkan dalam menjalankan mobilitas perusahaan terutama yang berhubungan dengan produksi yang bersinggungan langsung dengan profit dan target dari perusahaan (Mathis \& Jackson, 2006).

Kebun Ngobo merupakan perusahaan perkebunan yang berada dikawasan perindustrian. Hampir sebagian besar masyarakat disekitaran Kebun Ngobo lebih tertarik bekerja di industri ketimpang menjadi penyadap karet. Hal ini menjadikan Kebun Ngobo berada pada posisi dilema kebutuhan sumber daya manusia terkhususnya di tenaga penyadapan. Kebun Ngobo akan mengalami kesulitan di masa yang akan datang apabila tidak segera menentukan strategi yang tepat untuk menghadapi dilema kebutuhan tenaga kerja, sehingga tenaga kerja tidak menjadi permasalahan yang akan mengancam tujuan dari perusahaan.

Tujuan dari penelitian ini yaitu: (1) Mengidentifikasi dilema (antara harapan dan kenyataan) apa saja yang dihadapi oleh perusahaan dalam memilih kebutuhan tenaga kerja di Kebun Ngobo; (2) Mengetahui strategi perusahaan dalam menghadapi dilema kebutuhan tenaga kerja di Kebun Ngobo.

\section{Metode Penelitian}

Penelitian ini dilaksanakan di PT Perkebunan Nusantara IX (Kebun Ngobo), Kabupaten Semarang, Provinsi Jawa Tengah. Pemilihan lokasi penelitian secara sengaja (Purposive Sampling) karena PT Perkebunan Nusantara IX Kebun Ngobo merupakan salah satu perkebunan di Provinsi Jawa Tengah yang dapat menyerap tenaga kerja yang cukup besar dan berada dikawasan perindustrian. Waktu pelaksanaan penelitian ini pada tanggal 15 Maret sampai dengan 15 April 2019, atau diakhiri ketika data yang dibutuhkan sudah didapat dan dianggap jenuh.

Penelitian ini menggunakan jenis penelitian kualitatif dimana metode ini mampu memberikan hasil yang maksimal mengenai permasalahan yang akan diteliti. Dasar penelitian kualitatif merupakan pendalaman suatu permasalahan yang belum jelas terungkap, yang akan dipecahkan dengan cara lebih mendalam dengan sudut pandang tunggal dan lebih sedikit dari pada metode kuantitatif. Metode kualitatif adalah suatu penelitian yang ditujukan untuk mendeskripsikan dan menganalisis fenomena, peristiwa, aktivitas sosial, sikap, kepercayaan, presepsi, pemikiran orang secara individual maupun kelompok (Bachri, 2010).

Penelitian ini menggunakan metode penelitian deskriptif kualitatif agar mengungkap fakta/kenyataan sebenarnya, fenomena yang terjadi, variabel yang 
mempengaruhi pengambilan keputusan dalam kebijakan penentuan sumber daya manusia. Masalah yang diteliti dan diselidiki oleh penelitian saat ini mengacu pada perbedaan antara harapan dan fakta pada kebutuhan sumber daya manusia di perusahaan. Metode deskriptif kualitatif adalah suatu metode yang digunakan untuk menggambarkan atau menganalisis suatu hasil penelitian tetapi tidak digunakan untuk membuat kesimpulan yang lebih luas (Sugiyono, 2005).

Unit amatan adalah sesuatu yang dijadikan sumber untuk memperoleh data dalam rangka menggambarkan atau menjelaskan tentang satuan analisis (Ihalauw, 2003). Unit amatan dalam penelitian ini adalah Asisten Kepala, dan Asisten Produksi dan Staf SDM dan Umum di PT Perkebunan Nusantara IX Kebun Ngobo.

Teknik pengumpulan data yang digunakan pada penelitian adalah, wawancara, observasi partisipatif, dokumentasi, dan studi pustaka: (1) Wawancara : Wawancara adalah pertemuan dua orang untuk bertukar informasi dan ide melalui tanya jawab sehingga dapat dikonstruksikan makna dalam suatu topik tertentu dan dengan wawancara, peneliti akan mengetahui hal-hal yang lebih mendalam tentang partisipan dalam menginterprestasikan situasi dan fenomena yang terjadi yang tidak mungkin bisa ditemukan melalui observasi (Sugiyono, 2009). Pada penelitian ini peneliti menggunakan teknik wawancara terstruktur yang dimana peneliti telah menyiapkan instrumen penelitian berupa pertanyaan-pertanyaan tertulis yang alternatif jawaban telah disiapkan oleh informan, informan diberi pertanyaan yang sama kemudian peneliti mencatatnya atau menggunakan alat perekam sebagai alat bantu sehingga pelaksanaan wawancara dapat berjalan dengan lancar; (2) Observasi Partisipatif: Dalam observasi ini, peneliti terlibat dengan kegiatan sehari-hari orang yang sedang diamati atau yang digunakan sebagai sumber data penelitian. Peneliti ikut melakukan apa yang dikerjakan oleh sumber data (informan) dalam melaksanakan pekerjaannya sampai data yang dihasilkan oleh peneliti sudah jenuh. Dengan observasi partisipan ini, data yang diperoleh akan lebih lengkap, tajam, dan sampai mengetahui pada tingkat makna dari setiap perilaku yang tampak (Sugiyono, 2009); (3) Dokumentasi : Dokumentasi merupakan teknik pengumpulan data dengan cara memperoleh informasi dari bermacam-macam sumber tertulis atau dokumen yang ada pada informan atau tempat penelitian terjadi, dimana informan melakukan kegiatan sehari-harinya (Sugiyono, 2012); (4) Studi Pustaka : Studi pustaka adalah kajian teoritis, refrensi serta linteratur ilmiah lainnya yang berkaitan dengan budaya, nilai dan norma yang berkembang pada situasi yang diteliti. Studi pustaka dilakukan sebelum peneliti memulai penelitiannya, hal ini bertujuan diantaranya untuk menemukan informasi yang relevan sesuai dengan objek penelitian dan menambah pengetahuan mengenai masalah yang akan dijadikan objek penelitian (Sugiyono, 2012). Dalam penelitian ini terdapat 1 (satu) informan dan 2 (dua) key informan yang digunakan sebagai sumber data penelitian, berikut adalah gambaran umum partisipan ada pada Tabel 1.

Informan adalah mereka yang terlibat secara langsung dalam interaksi sosial yang diteliti (Suyanto, 2005). Penentuan Informan dipilih secara sengaja (purposive) dengan kriteria yang sudah ditentukan dan dianggap layak untuk mewakili perusahaan sesuai dengan permasalahan pada penelitian. Kriteria informan dalam penelitian ini yaitu memangku jabatan sebagai asisten produsi karena mengetahui secara rinci permasalahan yang ada dilapangan terkhususnya pada tenaga kerja dan memiliki wewenang untuk menentukan strategi yang tepat dalam penyelesaian masalah. Key informan adalah mereka yang mengetahui dan 
memiliki berbagai informasi pokok yang diperlukan dalam penelitian (Suyanto, 2005). Pada penelitian ini key informan yang dipilih yaitu Asisten Kepala dan Staf SDM dan Umum karena mereka berperan aktif dalam pengelolaan tenaga kerja yang ada di Kebun Ngobo.

Tabel 1

Informan dan key informan

\begin{tabular}{lllll}
\hline Status & Nama & Jabatan & $\begin{array}{l}\text { Lama } \\
\text { Menjabat }\end{array}$ & $\begin{array}{l}\text { Tingkat } \\
\text { Pendidikan }\end{array}$ \\
\hline Informan & $\begin{array}{l}\text { Antonius } \\
\text { Slamet } \\
\text { Ekosusanto }\end{array}$ & $\begin{array}{l}\text { Asisten } \\
\text { Kebun } \\
\text { Setro }\end{array}$ & 20 Tahun & S1 \\
\hline Informan Kunci 1 & $\begin{array}{l}\text { Angga } \\
\text { Agusta P }\end{array}$ & $\begin{array}{l}\text { Staf SDM } \\
\text { dan Umum }\end{array}$ & 3 Tahun & S1 \\
\hline Informan Kunci 2 & $\begin{array}{l}\text { Putut } \\
\text { Widiantoro }\end{array}$ & $\begin{array}{l}\text { Asisten } \\
\text { Kepala }\end{array}$ & 5 Tahun & S1 \\
& & &
\end{tabular}

Sumber : Hasil Wawancara, 2019

Uji keabsahan data pada penelitian ini menggunakan metode triangulasi, triangulasi diartikan sebagai teknik pengumpulan data yang bersifat menggabungkan dari berbagai teknik pengumpulan data dan sumber data yang telah ada (Sugiyono, 2009). Ada 2 jenis metode trianggulasi data pada penelitian ini: (1) Triangulasi sumber data adalah menggali kebenaran informai tertentu melalui berbagai metode dan sumber perolehan data. Misalnya, selain melalui wawancara dan observasi, peneliti bisa menggunakan observasi terlibat (participant obervation), dokumen tertulis, arsif, dokumen sejarah, catatan resmi, catatan atau tulisan pribadi dan gambar atau foto. Tentu masing-masing cara itu akan menghasilkan bukti atau data yang berbeda, yang selanjutnya akan memberikan pandangan (insights) yang berbeda pula mengenai fenomena yang diteliti. Berbagai pandangan itu akan melahirkan keluasan pengetahuan untuk memperoleh kebenaran handal (Rahardjo, 2010); (2) Triangulasi metode dilakukan dengan cara membandingkan informasi atau data dengan cara yang berdeda. Sebagaimana dikenal, dalam penelitian kualitatif peneliti menggunakan metode wawancara, obervasi, dan survei. Untuk memperoleh kebenaran informasi yang handal dan gambaran yang utuh mengenai informasi tertentu, peneliti bisa menggunakan metode wawancara bebas dan wawancara terstruktur. Atau, peneliti menggunakan wawancara dan obervasi atau pengamatan untuk mengecek kebenarannya. Selain itu, peneliti juga bisa menggunakan informan yang berbeda untuk mengecek kebenaran informasi tersebut. Melalui berbagai perspektif atau pandangan diharapkan diperoleh hasil yang mendekati kebenaran (Rahardjo, 2010).

Penelitian ini menggunakan teknik analisisi reduksi data. Reduksi data merupakan salah satu dari teknik analisis data kualitatif. Reduksi data adalah bentuk analisis yang menajamkan, menggolongkan, mengarahkan, membuang yang tidak perlu dan mengorganisasi data sedemikian rupa sehingga kesimpulan akhir dapat diambil oleh peneliti sebagai acuan penuliasan hasil penelitian. (Sutopo \& Arief, 2010). 


\section{Hasil Penelitian}

\section{A. Manajemen Sumber Daya Manusia}

\section{Pengadaan Tenaga Penyadap}

Pengadaan tenaga kerja dilakukan sebagai upaya Kebun Ngobo dalam mengisi dilema kekurangan tenaga kerja terkhususnya dipenyadapan karet. Kekurangan tenaga kerja penyadap dapat mengakibatkan kurangnya produksi karet yang dihasilkan sehingga akan berpengaruh langsung terhadap pendapatan Kebun Ngobo. Hal yang paling diperhatikan mengenai tenaga penyadap selalu mengutamakan masyarakat sekitaran Kebun Ngobo. Sangat tidak sulit untuk bekerja sebagai penyadap di Kebun Ngobo cukup ada kemauan saja sudah bisa bekerja disana jika belum memiliki skill maka akan diajarkan cara menyadap yang baik dan benar, harapannya agar masyarakat sekitar tertarik untuk bekerja di Kebun Ngobo.

"Jadi karena disini ada pekerjaan otomatis kan yang diutamakan masyarakat sekitar.

Rekuitmen itu hanya kita ambil dengan sistem gini, kalau mereka mau, asalkan mereka mau, ada kemauan ya kita ajak bekerja disini jadi tidak terus lewat tes gini-gini enggak." (I, 14-16)

Pada data dibawah ini dapat dilihat bahwa reqrutment karyawan HLT terakhir yang berumur di atas 50 tahun sebanyak 7 orang dan berpendidikan di bawah SMA sebanyak 14 orang. Hal ini disebabkan kurangnya minat masyarakat yang berumur produktif bekerja sebagai tenaga penyadap di Kebun Ngobo.

Tabel 2

Daftar Requretment Karyawan HLT Terakhir 2018

\begin{tabular}{lllllll}
\hline No & $\begin{array}{l}\text { Nama } \\
\text { Karyawan }\end{array}$ & Gol & L & $\mathbf{P}$ & Pendidikan & Umur \\
\hline 1 & SUMANAH & HLT & & 1 & Tidak Sekolah & 53 \\
2 & SURATMAN & HLT & 1 & & Tidak Sekolah & 54 \\
3 & SLAMET & HLT & 1 & & Tidak Sekolah & 47 \\
4 & KRISTIYONO & HLT & 1 & & SMP & 39 \\
5 & SARMAN & HLT & 1 & & SD & 34 \\
6 & UDIK & HLT & 1 & & SMP & 34 \\
& WIBOWO & & & & & \\
7 & SUMARNO & HLT & 1 & & SMA & 46 \\
8 & NGATINAH & HLT & & 1 & Tidak Sekolah & 52 \\
9 & ASNI & HLT & & 1 & Tidak Sekolah & 52 \\
10 & ROHMAD & HLT & 1 & & SD & 54 \\
11 & SUPONO & HLT & 1 & & SD & 53 \\
12 & TUGIYATNO & HLT & 1 & & SMP & 34 \\
13 & SUDARTO & HLT & 1 & & Tidak Sekolah & 54 \\
14 & RUMIYADI & HLT & 1 & & SMP & 34 \\
15 & SUROTO & HLT & 1 & & SD & 36 \\
\hline
\end{tabular}

(Sumber: Data Reqrutment Terahir Karyawan HLT Kebun Ngobo 2018)

Untuk kenyataan saat ini kebutuhan tenaga kerja di Kebun Ngobo masih kurang karena masyarakat disekitar lebih cendrung memilih bekerja dipabrik ketimbang dikebun. 
Untuk mengatasi masalah tersebut strategi yang dilakukan Kebun Ngobo yaitu: melakukan penjaringan tenaga kerja dari masyarkat sekitar hingga keluar Kabupaten Semarang, mempermudah dalam penerimaan tenaga penyadapan, memperdayakan karyawan pensiunan sebagai tenaga kerja, dan memanfaatkan tenaga kerja yang sudah berumur diatas 40 tahun yang tidak memungkinkan bekerja diindustri.

"Kalau dipabrikan umur 40 keatas itukan gak diterima nah kita manfaatkan itu mereka yang butuh kerja kita ajari itu karena dilingkungan pabrik usia segitu gak bakalan diterima." (K2, 62-64)

\section{Pelatihan Tenaga Penyadap}

Pelatihan tenaga penyadap dilakukan setiap 6 bulan sekali oleh Kebun Ngobo, kegiatan ini dilakukan sebagai bentuk kepedulian dalam meningkatkan kualitas dari tenaga penyadap mengenai cara penyadapan yang benar dan teknik-teknik mengenai produksi karet di Kebun Ngobo, yang biasa di sebut oleh Kebun Ngobo job training. Plating school merupakan kegiatan yang dilakukan setiap hari sabtu mengenai pemberian pelatihan perminggu dan informasi-informasi yang berkembang di perusahaan di setiap kemandoran, jumlah yang dilatih sesuai dengan anggota kemandoran, materi kegiatan ini disampaikan langsung oleh Asisten Afdeling. Adanya job training dan plating school tenaga penyadap diharapkan dapat mengimplementasikan kemampuan yang didapat selama pelatihan sehingga hasil produksi yang diperoleh dapat maksimal. Dengan adanya kegiatan semacam ini Kebun Ngobo berharap terkhususnya bagi karyawan penyadap mendapatkan keahlian tambahan yang akan meningkatkan kinerja dan produksi yang dihasilkan

"Job training itu terdiri dari job training mandor, job traning karyawan, dan job training karyawan yang mengampuh dibidangnya masing-masing. Karywan dibidang penyadap per 6 bulan itu pasti ada pelatihan, ada sebuah pengamatan gimana toh cara menyadap yang baik" (K1, 8-11)

"Setiap hari sabtu plating school itu memberikan sebuah wawasan memberikan pengetahuan disamping itu juga memberukan informasi seperti apasih perusahaan kita sekarang disamping itu juga memberikan motivasi dan terutama praktik mereka untuk bisa menyadap dengan benar gimana gitu”. (I, 24-27)

Sesuai dengan hasil observasi di lapangan, kenyataan yang terjadi tenaga penyadap diberi pelatihan yang dilakukan oleh perusahaan, hal tersebut dirasa sangat membantu menambah pengetahuan tenga penyadap mengenai teknik penyadapan yang baik dan benar, sehingga target produksi perusahaan dapat tercapai.

\section{Kompensasi Tenaga Penyadap}

Konpensasi yang diberikan Kebun Ngobo kepada tenaga penyadap dalam bentuk pemberian bonus setiap tahunnya. Pemberian kompensasi dilakukan dalam bentuk uang yang diterima karyawan terkhususnya bagi karyawan yang memiliki kinerja yang bagus selama setahun, untuk nominal yang diberikan perusahaan tergantung dari keuntungan yang didapat, biasanya sebulan gaji. Pembarian kompensasi diharapkan mampu menjadi daya tarik tersendiri untuk masuk dan bekerja di Kebun Ngobo. 
"Kompensasi bonus kepada karyawan jelas diberikan dari bentuk apapun meski diberikan apalagi bagi mereka yang betul betul berprestasi itu nanti istilahnya apa ya dalam reward tersendiri." (I, 28-29)

"Kalau bonus ya dalam bentuk uang." (I, 30)

"Kalau untuk bonus setiap tahun pasti ada, pertengahan tahun antara sebualan gaji itu mesti ada. Tapi satu tahun sekali mesti sejenis seperti THR itulah.” (K1, 14-15)

Akan tetapi kenyataan pada saat ini, pemberian kompensasi yang dilakukan Kebun Ngobo belum bisa menjadi daya tarik yang besar untuk mengisi kekosongan tenaga penyadap yang ada, hal tersebut tercermin dari kurangnya tenaga penyadap yang sesuai dengan kebutuhan perusahaan.

\section{Kebebasan Berpendapat Karyawan Penyadap}

Kebun Ngobo selalu memberi ruang kepada karyawan untuk selalu memberikan pendapatnya kepada atasan asalkan untuk kemajuan perusahaan. Kebebasan berpendapat diharapkan dapat menjadi daya tarik tersendiri untuk memperoleh karyawan penyadap yang berkualitas, menambah kuota tenaga penyadap yang pada saat ini mengalami devisit, dan menjaga kesetiaan tenaga penyadap.

"Ya kalau kebebasan y selama kebebasan itu dalam arti berpendapat untuk membangun kemajuan perusahaan itu jelas, jadi saya sendiri pun disini dengan teman-teman pengawas itu monggo siapa yang punya ide asalkan untuk kemajuan updeling ini ya ayok kita pakek tinggal nanti ditengah perjalanan kok ada kesulitan kita atasi bareng-bareng jadi gak harus gini-gini enggak." (I, 39-42)

Hal tersebut dibenarkan oleh key informan satu dan dua yang menyebutkan bahwa di Kebun Ngobo memberikan kebebasan berkomunikasi kepada atasan-atasan sehingga memberikan efek transparansi komunikasi yang berbuntut pada informasi-informasi yang lancar. Waktu yang tidak terikat mejadikan tenaga penyadap dapat bekerja di bidanglainnya, bekerja sebagai penyadap dapat menjadi pekerjaan pokok dan juga sebagai pekerjaan sampingan. Hal yang paling terpenting di Kebun Ngobo adalah ketercapaian terget sesuai dengan yang ditetapkan oleh perusahaan. Perusahaan dapat merugi jika karyawan tidak mendapatkan hasil sesuai dengan target yang ada ditambah lagi kurangnya tenaga penyadap yang mengakibatkan ada beberapa ancak/blok yang tidak disadap ataupun rotasi penyadapan yang panjang.

"Oh bebas disikan kita demokratis ya harus bebas kita buka ruang komunikasi sehingga biar transparansi komunikasi itu lebih erat sehingga komunikasinya tidak buntu informasiinformasi lancar sehingga wajib hukumnya komunikasi dengan mandor harus dekat dengan penyadap." (K2, 22-24)

"Karyawan cenderung bebas terlebih kita lihat dari waktunya bekerja, tidak ada antara pantangan khusus kamu harus masuk jam segini jam segini enggak yang penting hasil yang kita dapat sesuai dengan target yang sudah ditentukan." (K1, 17-19)

Kenyataan yang Saya temui dilapangan, benar saja setiap ada keluhan dari tenaga penyadap selalu disampaikan langsung kepada Mandor kebun hingga keAsisten kebun, hal seperti inilah yang diharapkan Kebun Ngobo agar setiap ada informasi-informasi yang ada 
dilapangan cepat diketahui oleh atasan, terlebih mengenai keadaan yang terjadi di lapangan dan segera dicarikan solusinya.

\section{Strategi Menjaga Loyalitas Karyawan Penyadap}

Loyalitas karyawan pada suatu perusahaan ditunjukan dengan komitmen karyawan didalam perusahaan, komitmen loyal pada perusahaan bisa terjadi karena adanya kesadaran karyawan pentingnya membangun rasa memiliki perusahaan didalam pekerjaan. Di Kebun Ngobo strategi yang digunakan untuk menjaga rasa setia kepada Kebun Ngobo yaitu dengan pendekatan secara kekeluargaan. Pendekatan secara kekeluargaan dirasa mampu menjadi benteng pertahaan untuk keberlanjutan perusahaan ini.

"Yang jelas kembali lagi ke reward atau sebuah penghargaan terutama kepada mereka yang berprestasi taruhlah seperti kemarin ada gangguan luar kita bisa antisispasi dengan cara pendekatan secara kekeluargaan." (I, 43-45)

Strategi pengangkatan jabatan juga sedang dilakukan Kebun Ngobo sebagai upaya menjaga rasa setianya kepada perusahaan. Pengangkatan karyawan dapat berupa kenaikan golongan dari HLL (Harian Lepas Lain-Lain) dan HLT (Harian Lepas Teratur) menjadi semi tetap atau golongan $1 \mathrm{~A}$. Kelebihan dari golongan 1 A yaitu adanya dana-dana indentif yang diperoleh dari Kebun Ngobo setiap bulannya, kalau HLL dan HLT pendapatan hanya berdasarkan hasil yang diperoleh perharinya dan dibayarkan setiap 1 minggu sekali. Hal tersebut diharapkan mampu menjaga loyalitas terkhususnya tenaga penyadap terhadap perusahaan.

"Kalau untuk mempertahankan karyawan tiap tahun mesti ada requitment tidak terlepas dari pengangkatan antar golongan ini ke golongan ini ke golongan satu ke golongan yang berbeda mesti ada. Mungkin kalau untuk mempertahankan eksistensi karyawan ada pengangkatan setiap tahun." (K1, 20-22)

Pada kenyataan saat ini permasalahan sering keluar masuknya karyawan menjadikan tantangaan tersendiri bagi Kebun Ngobo dalam berkompetisi di lingkungan perindustrian. Ada beberapa karyawan yang ingin mencoba-coba bekerja di penyadapan kemudian bosan dan mencari pekerjaan di industri, setelah mendapatkan pekerjaan di industri, dirasa tidak enak ingin kembali lagi ke Kebun Ngobo. Hal yang seperti ini dapat mengganggu kestabilan pendapatan produksi karet perusahaan, Kebun Ngobo tidak melarang tindakan yang seperti itu. Strategi yang digunakan untuk mengatasi permasalahan tersebut yaitu : jika ada karyawan yang sudah berstatus $1 \mathrm{~A}$ berprilaku seperti itu maka karyawan yang sudah berstatus $1 \mathrm{~A}$ akan menjadi karyawan borongan jika kembali bekerja sebagai tenaga penyadap.

"Keluar masuk itu jadi mereka pengen nyoba tarohlah coba diperusahaan luar garmen lah, mereka di garmen bosan keluar lagi, masuk lagi ke sini disini bosan kadang keluar lagi.." (I, 103-104)

\section{Strategi Manajemen Sumber Daya Manusia Kebun Ngobo}

Strategi manajemen dapat dilihat sebagai tantangan perusahaan mengenai cara mendapatkan dan mempertahankan keunggulan kompetitif perusahaan. Pengelolaan sumber daya manusia yang baik dapat menjadi sebuah keunggulan bersaing terhadap perusahaan 
industri-industri yang ada disekeliling Kebun Ngobo. Strategi manajemen sumberdaya manusia yang mempunyai skill dan dinamis menjadi strategi yang digunakan Kebun Ngobo untuk menjawab keadaan sumber daya manusia saat ini. Kebun Ngobo akan mengupgrade kemampuan yang dimiliki karyawan agar mampu mengikuti perkembangan jaman. Harapannya walaupun kekurangan tenaga penyadap Kebun Ngobo harus mampu memberikan hasil produksi yang baik.

"Manajemen sumber daya manusia ya sumberdaya manusia yang mempunyai kemampuan skill dan dinamis berubah bergerak jadi kalau gak statis manusia nya harus kita upgrade terus ya disitu sehingga bisa mengikuti perkembangan jaman." (K2, 31-33)

Kenyataan yang terjadi pada saat ini, walaupun Kebun Ngobo masih kekurangan tenaga penyadap, berkat tenaga penyadap yang berkompeten, Kebun Ngobo masih mendapatkan hasil produksi yang dapat membiayai mobilitas perusahaan.

\section{Rencana Penanganan Tenaga Penyadap}

Data dibawah ini menjelaskan adanya dilema yang dihadapi Kebun Ngobo sebagai salah satu perusahan perkebunan yang berada di daerah perindustrian. Salah satunya yaitu adanya ketidak sesuaian dengan harapan perusahaan terhadap karyawan dari segi umur. Dapat kita lihat masih banyaknya tenaga yang sudah berumur diatas 50 tahun dan masih bekerja di Kebun Ngobo. Sebagian besar karyawan tersebut merupakan tenaga penyadap yang menggantungkan kehidupannya dari Kebun Ngobo, dan merupakan karyawan pensiunan yang merasa masih mampu untuk bekerja sebagai penyadap. Hampir sebagian besar masyarakat yang berumur produktif lebih memilih bekerja di industri karena lebih menarik ketimbang sebagai penyadap karet. Pekerjaan penyadap karet dipandang masyarakat sana sebagai pekerjaan buruh kasar yang memiliki status gengsi paling bawah, ditambah pekerjaan penyadapan dimulai dari subuh sekitar jam 03.00 wib dan bercengkrama dengan bau busuk khas karet. Hal tersebut membuat anak muda "gengsi" memiliki pekerjaan sebagai penyadap karet, dan lebih didominasi oleh tenga-tenaga yang sudah diatas 50 tahun.

Tabel 2

\section{Umur Karyawan Kebun Ngobo}

\begin{tabular}{lllllll}
\hline $\begin{array}{l}\text { Kelompok } \\
\text { Umur }\end{array}$ & $\begin{array}{l}\text { Karyawan } \\
\text { Pimpinan }\end{array}$ & $\begin{array}{l}\text { Karyawan } \\
\text { Pelaksana }\end{array}$ & $\begin{array}{l}\text { Karyawan } \\
\text { Pembantu }\end{array}$ & $\begin{array}{l}\text { Kayawan } \\
\text { HL } \\
\text { Teratur }\end{array}$ & $\begin{array}{l}\text { Karyawan } \\
\text { Skill }\end{array}$ & $\begin{array}{l}\text { Karyawaan } \\
\text { Jumlah }\end{array}$ \\
\hline $55-59$ & 1 & 23 & 3 & & 83 & 87 \\
$50-54$ & 2 & 21 & 60 & 29 & 35 & 149 \\
$45-49$ & 3 & 11 & 36 & 21 & 24 & 105 \\
$40-44$ & 2 & 5 & 23 & 19 & 34 & 89 \\
$35-39$ & - & - & 14 & 22 & 33 & 74 \\
$30-34$ & - & - & 8 & 22 & 43 & 73 \\
$25-29$ & - & - & 4 & 8 & 48 & 60 \\
$20-24$ & - & - & - & - & 27 & 27 \\
\hline Jumlah & 8 & 60 & 148 & 121 & 327 & 664 \\
\hline
\end{tabular}

(Sumber Data Karyawan Kebun Ngobo 2019)

Dilema tenaga kerja akan dialami setiap perusahaan terutama yang bergerak di perkebunan. Dilema tenaga kerja menjadi permasalahan yang sangat sulit untuk dihindari karena bersinggungan langsung dengan karakteristik seseorang yang sulit untuk dipaksakan. 
Harapan Kebun Ngobo ingin mendapatkan karyawan yang masih produktif dari segi umur. Faktor eksternal juga dapat menjadi masalah ketika perusahaan tidak dapat berkompotitor dengan baik. Kebun Ngobo yang berada disekitaran perindustrian besar menjadi tantangan tersendiri untuk menarik minat tenaga kerja produktif untuk menjadi bagian dari Kebun Ngobo, akan tetapi pada kenyataan sekarang Kebun Ngobo masih belum dapat bersaing dengan perusahaan yang lain terkhususnya bidang industri yang lebih banyak diminati oleh masyarakat sekitar. Dampaknya pada saat ini Kebun Ngobo masih devisit tenaga kerja umur produktif pada penyadapan karet.

\section{B. Peramalan Sumber Daya Manusia}

\section{Faktor-Faktor yang Mempengaruhi Ramalan Karyawan Penyadap}

(1) Berada di lingkungan perindustrian menjadi tantangan tersendiri Kebun Ngobo yang bergerak di bidang perkebunan terkhususnya dari segi kebutuhan tenaga kerja. Kenyataan pada saat ini bekerja di bidang industri menjadi daya tarik tersendiri bagi masyarakat sekitar, anak-anak muda menjadikan industri sebagai tempat utama mencari pendapatan dalam memenuhi kebutuhan hidup. Kurangnya minat tenaga yang berusia produktif menjadikan tantangan Kebun Ngobo dalam memenuhi kebutuhan tenaga kerja terkhusus dipenyadapan;

"Faktor yang mempengaruhi kebutuhan tenaga kerja di perusahaan ini yang jelas karena kita perusahaan perkebunan karena lingkungan kita itu lingkungan industri yang jelas faktor-faktor yang memepengaruhi itu ya dengan berdirinya banyak-banyak industri di sekitar kita itu aja.." (I, 65-67)

(2) Dari segi upah yang diterima, strategi Kebun Ngobo menawarkan pendapatan diatas UMK yang sudah ditetapkan asalkan setiap harinya karyawan selalu melebihi basis target yang sudah ada; (3) Lingkungan menjadi faktor pendukung dalam ramalan kebutuhan tenaga kerja, akan tetapi lingkungan di Kebun Ngobo sangat tidak menguntungkan karena berada dikawasan industri yang lebih banyak peminatnya; (4) kenyamanan dan suasana karyawan bekerja, biasanya permasalahan ini berkenaan dengan waktu pekerjaan, kegiatan menyadap karet dilakukan sebelum matahari terbit, bahkan di Kebun Ngobo karyawan mulai melakukan kegiatan penyadapan Pukul 03.00 WIB, hal tersebut dapat menjadi bahan pertimbangan bagi calon karyawan yang mau masuk sebagai tenaga penyadap. Harapan dari Kebun Ngobo sendiri memiliki karyawan yang berdaya saing yang tinggi sesuai dengan visi perusahaan yang ada.

"kita UMK sama mereka juga UMK malah kalau yang HLT malah banyak kita loh, UMK plus minggu dibayar, uang pakaian kerja dapat, uang BHL dapat dan bonus." $(K 2,55-56)$

"Jelas upah, kemudian kenyamanan karyawan bekerja, lingkungan kerja kemudian juga ya suasana kerja." (K2, 39)

\section{Teknik Memperkirakan Kebutuhan Karyawan Penyadap}

Dalam memperkirakan kebutuhan tenaga penyadap Kebun Ngobo selalu mengacu dengan RKAP (Rencana Kerja Anggaran Perusahaan), RKAP dibuat setiap tahun mengenai pengeluaran yang akan dikeluarkan pada tahun anggaran. Hal-hal yang mengenai pembiayaan 
di Kebun Ngobo sudah dianggarkan didalam RKAP tahunan, sehingga semua mengacu pada RKAP yang sudah ditetapkan. Pada tahap ini dilema megenai kebutuhan tenga penyadap akan kelihatan, apakah tenaga penyadap sudah terpenuhi sesuai RKAP ataupun kekurangan bahkan kelebihan tenaga penyadap. Harapannya dengan adanya RKAP ini menjadi patokan dari setiap pembiayaan perusahaan, agar tidak terjadinya lebih budged dan mereamalkan kebutuhan tenaga penyadap yang diperlukan.

"Untuk penentuan tenaga kerja disini itu sudah ada patokan jadi oh ini loh luas ada sekian ha. Per ha itu harus di isi taruhlah dipenyadapan ya satu tahun tanam itu ada 25 ribu pohon, 25 ribu pohon ini mau kita jadikan berapa, sistemnya gini karyawan penyadap itu sudah di kasi bagian sendiri-sendiri per blok jadi satu karyawan dikasi istilahnya itu ancak per blok ini mau kita patok berapa pohon per orang taruhlah 500 pohon per orang tinggal 25 ribu dibagi 4 blok kita bagi 500 jadi disitulah kebutuhan tenaga kerja dalam satu tahun tanam." (I, 75-80)

Kenyataannya kekurangan tenaga penyadap dapat diketahui dengan patokan RKAP. RKAP tidak akan mengalami lebih budged karena sudah dipatok perbloknya dengan sistem WBS dibutuhkan berapa, jika mengalami lebih budged maka tidak akan dilakukan transfer antar rekening.

"Memang sudah dihitung apalagi dengan sekarangkan sudah mengunakan sistem BWS / sudah perblok, blok ini sekian blok ini sekian, kalau blok ini sekian sudah habis anggarannya ya sudah, gak boleh transfer antar rekening." (I, 89-91)

\section{Rencana Pengadaan Tenaga Penyadap}

Dilema kebutuhan tenaga kerja penyadap menjadi tantangan bagi Kebun Ngobo. Untuk saat ini strategi yang digunakan Kebun Ngobo yaitu : melakukan pendekatan dengan masyarakat sekitar untuk menarik perhatian, tidak mempersulit masuk bekerja, menerima karyawan yang sudah berumur diatas 40 tahun, dan pengadaan dari luar daerah Kebun Ngobo, dengan adanya strategi ini diharapkan mampu membrikan produksi yang baik walaupun kekurangan tenaga penyadap. Kenyataannya ketidak sesuaian dengan yang diharapkan membuat kendala dari segi tenaga penyadap, sebagai contoh kurangnya tenaga penyadap membuat rotasi penyadapan menjadi panjang, yang idealnya 2 hari sekali disadap akan tetapi menjadi 4 hari sekali baru bisa disadap.

"Setiap membuat RKAP itu, RKAP itu kan umumnya di $R$ prosesi, $R$ prosesi itu isinya hektaran nah ini ketahuan kebutuhan tenaga kerja apa aja ada berapa sih kebutuhan tenaga penyadapnya udah ya dinamis setiap tahun berubah." (K2, 43-45)

\section{Hambatan Perencanaan Kebutuhan Tenaga Penyadap}

Hambatan selalu hadir disetiap perencanaan, terlebih hal itu mengenai kebutuhan karyawan. Posisi Kebun Ngobo yang berada dikawasan perindustrian sangat mempengaruhi perencanaan kebutuhan karyawan penyadap. Harapan Kebun Ngobo walaupun dengan keadaan kekurangan tenaga penyadap, karyawan hendaknya loyal terhadap perusahaan, agar tidak memperburuk keadaaan.

"Yang jelas karena kita perusahaan perkebunan karena lingkungan kita itu lingkungan industri yang jelas faktor-faktor yang memepengaruhi itu ya dengan berdirinya banyakbanyak industri di sekitar kita." (I, 65-67) 
Kenyataan pada saat ini kehadiran perindustrian sangat mempengaruhi keberadaan karyawan penyadapan, karena akan membut karyawan keluar masuk perusahaan karena ingin mencoba bekrja di industri akan tetapi setelah bosan akan kembali lagi ke Kebun Ngobo. Tindakan ini sangat berpengaruh terhadap keadaan perusahaan karena sulit untuk diperkirakan dari tindakan mereka tersebut.

"Itu keluar masuk itu jadi mereka pengen nyoba tarohlah coba diperusahaan luar garmen lah mereka di garmen bosan keluar lagi masuk lagi ke sini disini bosan kadang keluar lagi yang terjadi kesulintan seperti itu." (I, 102-104)

\section{Pentingnya MSDM dan Peramalan SDM Dalam Mobilitas Perusahaan}

Pada kasus di Kebun Ngobo, perusahaan sudah melakukan segala upaya untuk menyelesaikan permasalahan sumber daya manusia terkhususnya pada tenaga penyadap dengan memadukan unsur-unaur yang ada pada MSDM dan Perencanaan SDM. Keunggulan dalam persaingan antar perusahaan di sekitaran Kebun Ngobo, sangat ditentukan antara lain oleh strategi MSDM dan Perencanaan SDM yang dilakukan oleh perusahaan. Dengan strategi manajemen sumber daya manusia dan Perencanaan SDM yang tepat, keunggulan tenaga penyadap yang dimiliki perusahaan diharapkan dapat mendukung pencapaian keunggulan bersaing, walaupun pada saat ini Kebun Ngobo masih menghadapi permasalahan dilema kebutuhan tenaga penyadap, Kebun Ngobo masih dapat menjalankan mobilitas bisnisnya.

Pada jurnal Farchan (2017) Peran strategis MSDM dalam perusahaan dapat dielaborasi dari segi teori sumber daya manusia, di mana fungsi perusahaa adalah mengerahkan seluruh sumber daya atau kemampuan internal untuk menghadapi permasalahan sebagai faktor eksternal utama. Strategi MSDM yang memberikan nilai tambah (added value) sebagai tolok ukur keberhasilan bisnis. Kemampuan MSDM ini merupakan competitive advantage dari perusahaan. Dengan demikian, dari segi sumber daya, strategi bisnis adalah mendapatkan added value yang maksimum yang dapat mengoptimumkan competitive advantage. (Farchan, 2017)

Sehingga pada abad 21 ini, persaingan untuk mendapatkan tenaga kerja yang profesional sangat ketat karena perusahaan menginginkan tenaga kerja yang dapat bekerja secara efisien. Maka perusahaan sangat memperhatikan perencanaan tenaga kerja untuk masa yang akan datang. Satu hal yang tidak boleh diabaikan dalam praktek organisasi adalah pentingnya integrasi atau keterpaduan antara perencanaan bisnis dengan perencanaan SDM. (Samanto, 2015)

\section{Kesimpulan}

Dari hasil penelitian dan pembahasan, maka peneliti dapat menarik kesimpulan sebagai berikuat: (1) Dalam pelaksanaannya Kebun Ngobo mengalami beberapa dilema kebutuhan tenaga penyadap (tidak sesuai antara harapan dan kenyataan) yaitu: Manajemen Sumber Daya Manusia (MSDM), meliputi pengadaan tenaga penyadap, kompensasi tenaga kerja penyadap, strategi menjaga loyalitas tenaga penyadap, rencana penanganan karyawan penyadap. Sedangkan peramalan Sumber Daya Manusia, meliputi faktor-faktor yang mempengaruhi ramalan karyawan penyadap, rencana pengadaan karyawan penyadap, hambatan perencanaan kebutuhan karyawan penyadap; (2) Strategi Kebun Ngobo dalam 
menghadapi dilema kebutuhan tenaga kerja, meliputi: strategi pengadaan tenaga penyadap Kebun Ngobo yaitu: melakukan penjaringan tenaga kerja dari masyarkat sekitar hingga keluar Kabupaten Semarang, mempermudah dalam penerimaan tenaga penyadapan, memperdayakan karyawan pensiunan sebagai tenaga kerja, dan memanfaatkan tenaga kerja yang sudah berumur diatas 40 tahun yang tidak memungkinkan bekerja di industri. Strategi menjaga loyalitas tenaga penyadap, dengan pendekatan secara kekeluargaan dan pengangkatan jabatan. Strategi yang digunakan Kebun Ngobo dalam menghadapi faktor-faktor yang mempengaruhi ramalan karyawan penyadap yaitu menawarkan pendapatan diatas UMK bagi karyawan yang melebihi basis target yang sudah ada. Strategi yang digunakan dalam perencana pengadaan karyawan penyadap Kebun Ngobo yaitu: melakukan pendekatan dengan masyarakat sekitar untuk menarik perhatian, tidak mempersulit masuk bekerja, menerima karyawan yang sudah berumur diatas 40 tahun, dan pengadaan dari luar daerah Kebun Ngobo, sementara untuk dilema yang lainnya Kebun Ngobo belum memiliki strategi penanganan.

\section{Daftar Pustaka}

Bachri, B. S. (2010) 'Teknologi Pendidikan', Vol.10, No. 1.

Farchan, F. (2017) 'Strategi MSDM Sebuah Cara Menciptakan Kinerja Otganisasi Dalam Mencapai Keunggulan Bersaing', Jurnal Pendidikan dan Studi Islam, Vol. 04, No. 01.

Ihalauw (2003) Manajemen Sumber Daya Manausia. Salatiga: Fakultas Ekonomi dan Bisnis UKSW.

Mathis, R.L; Jackson, J. (2006) Human Resource Management: Manajemen Sumber Daya.

Manusia. Edited by D. Angelia. Jakarta: Selemba Empat.

Prihantoro, A. (2012) 'Peningkatan Kinerja Sumber Daya Manusia Melalui Motivasi, Disiplin, Lingkungan Kerja, dan Komitmen', Vol. 08, NO. 02.

Rahardjo, M. (2010) Trianggulasi Dalam Penelitian Kualitatif. Malang: UIN Maulana Malik Ibrahim.

Samanto, H. (2015) 'Perencanaan dan Perekrutan Sumber Daya Mamusia Abad 21', Akuntansi dan Pajak, Vol. 15, No,. 02.

Sugiyono (2005) Metode Penelitian Administrasi. Bandung: Alfabeta.

Sugiyono $(2009,2012)$ Metode Penelitian Pendekatan Kuantitatif, Kualitatif, dan R \& D. Bandung: Alfabeta.

Suheerman, R. (2009) Pengantar Teori Ekonomi. Jakarta: Rajawali.

Sutopo, A.H; Arief, A. (2010) Trampil Mengolah Data Kualitatif Dengan NVIVO. Jakarta: Pranada Media Group.

Suyanto (2005) Metode Penelitian Sosial. Jakarta: Kencana Prenada Media Group.

Widajanti, E. (2007) Perencanaan Sumber Daya Manusia yang Efektif: Starategi Mencapai Keunggulan Komperatif. Surakarta: Fakultas Ekonomi Universitas Slamet Riyadi. 